\title{
MODEL PARTICIPATION ACTION RESEARCH DALAM PEMBERDAYAAN MASYARAKAT
}

\author{
Abdul Rahmat, Mira Mirnawati \\ Universitas Negeri Gorontalo \\ abdulrahmat@ung.ac.id
}

Received: 10 Desember 2019; Revised: 17 Desember 2019; Accepted: 24 Desember 2019

\begin{abstract}
ABSTRAK
Tulisan ini akan menguraikan tentang action research (penelitian tindakan) sebagai salah satu alternatif metode penelitian dalam studi dan aksi pemberdayaan masyarakat. Penelitian tindakan didasarkan kepada asumsi bahwa penelitian harus dihubungkan dengan agenda perubahan dalam masyarakat. Penelitian tindakan dilakukan tidak hanya untuk memperoleh kebenaran semata namun juga menciptakan kondisi yang diharapkan. Penelitian tindakan dapat digunakan secara efektif dalam kajian maupun aksi pemberdayaan masyarakat mengingat karakteristiknya yang mementingkan partisipasi warga masyarakat secara aktif. Melalui penelitian tindakan akan dapat dihasilkan formula yang sesuai dengan kondisi masyarakat dalam melakukan upaya pemberdayaan masyarakat.
\end{abstract}

Kata Kunci: penelitian tindakan, pemberdayaan, partisipasi masyarakat.

\section{PENDAHULUAN}

Partisipasi Masyarakat dan Pembangunan

Pembangunan yang baik adalah pembangunan yang berbasiskan partisipasi. Konsep partisipasi ataupun partnership dan participationini pertama kali diperdengarkan pada Laporan Konferensi PBB tentang Pemukiman Manusia (Habitat II) di Istambul Turkey 3-14 Juni 1996 yang menyatakan bahwa partisipasi merupakan pendekatan yang paling demokratis dan efektif untuk mewujudkan suatu tujuan pembangunan dengan cara mengadopsi strategi yang memungkinkan dan prinsip- prinsip kemitraan/partisipasi(UNCHS,1996:9). Partisipasi (dalam terminologi UNHCS disebut sebagai forum konsultasi warga) yang merupakan platform bagi semua stakeholder guna mendiskusikan berbagai isu pembangunan dan menghasilkan konsensus terkait prioritasi pelaksanaan program-program pembangunan. Struktur forum konsultasi warga seyogyanya terdiri dari tiga unsur, yaitu pemerintah,organisasi masyarakat dan lembaga non-pemerintah. Pembentukan forum warga menjadi semacam wahana bagi pelibatan masyarakat/stakeholder (stakeholder engagement) dalam proses konsultasi warga (UNHCS, 2001).

Di Indonesia, program pembangunan yang selama ini dilakukan pemerintah masih bersifat pola pendekatan pembangunan top-down(dari atas ke bawah)yang menunjukkan perandominan dari pemerintah. Pemerintah melakukan pembangunan tanpa melihat apakah program tersebut benar-benar dibutuhkan masyarakat atau tidak sehingga program yang ada menjadi tidak tepat sasaran dan tujuan pembangunan Indonesia untuk mencapai masyarakat yang adil dan makmur tidak terwujud.

Pada masa sekarang ini, paradigma program pembangunan sudah bergeser menjadi pola pendekatan pembangunan bersifat bottom-up(dari bawah ke atas). Partisipasi aktif masyarakat menjadi landasan utama pada program pembangunan yang bersifat 
bottom-up. Masyarakat dijadikan sebagai subjek pembangunan bukan lagi menjadi objek pembangunan. Masyarakat diikutsertakan dalam menentukanberbagai kegiatan pembangunan, dan pengelola program pembangunan sehingga peran pemerintah bergeser menjadi fasilitator, sumber biaya, dan sumber inovasi dalam pencapaian tujuan program. Hal-hal inilah yang disebut dengan pembangunan partisipatif, dimana pembangunan yang dilakukan berlandaskan peran serta masyarakat sehinggatujuan program pembangunan tercapai dan hasilnya dapat dinikmati masyarakat luas.

Pelibatan masyarakat pada setiap tahapan pembangunan dimulai dari perencanaan, pelaksanaan, pemanfaatan dan pemeliharaan, akan menumbuhkan rasa percaya terhadap pemerintah sehingga masyarakat termotivasi untuk mendukung program-program pembangunan yang dilakukan pemerintah. Masyarakat banyak memegang peran penting dalam pembangunan sehingga partisipasi aktif dari masyarakat mutlak diperlukan. Keberhasilan program pembangunan pemerintah sangat tergantung pada partisipasi masyarakat. Bila tingkat partisipasi masyarakat tinggi maka tinggi pulalah tingkat keberhasilan program tersebut. Hal ini membuktikan bahwa partisipasimasyarakat adalahhal yang sangat menentukan bisa atau tidaknya tujuan pembangunan tercapai. Oleh karena itu kunci sukses pembangunan adalah partisipasi masyarakat.

\section{Program Nasional Pemberdayaan Masyarakat (PNPM) Mandiri Perkotaan di Kelurahan Bagan Deli}

Program Nasional Pemberdayaan Masyarakat (PNPM) Mandiri Perkotaan merupakansalah satu program pembangunan pemerintah yang bertujuan untuk menanggulangi kemiskinan melalui peningkatan kesejahteraan dan kesempatan kerja masyarakat miskin secara mandiri dengan berbasis pemberdayaan masyarakat. Program Nasional Pemberdayaan Masyarakat (PNPM) Mandiri Perkotaan ini sangat strategis karena menyiapkan landasankemandirian masyarakat berupa lembaga kepemimpinan masyarakat yangrepresentatif, mengakar dan kondusif bagi perkembangan modal sosial (socialcapital) masyarakat di masa mendatang serta menyiapkan program masyarakat jangka menengah dalam penanggulangan kemiskinan yang menjadi pengikat dalamkemitraan masyarakat dengan pemerintah daerah dan kelompok peduli setempat.

Program Nasional Pemberdayaan Masyarakat (PNPM) Mandiri Perkotaan ini dimulai sejak tahun 2008, dimana program ini merupakan program lanjutan dari Program Penanggulangan Kemiskinan di Perkotaan (P2KP) yang telah dilaksanakan pemerintah sejaktahun 1999 sebagai suatu upaya pemerintah untuk membangun kemandirianmasyarakat dan pemerintah daerah dalam menanggulangi kemiskinan secaraberkelanjutan.

Adapun salah satu yang menjadi tujuan khusus Program Nasional Pemberdayaan Masyarakat (PNPM) Mandiri Perkotaan ini adalah untuk meningkatkan partisipasi seluruh masyarakat, termasuk masyarakat miskin, kelompok perempuan, komunitas masyarakat terpencil, dan kelompok masyarakat lainnya yang rentan dan sering terpinggirkan ke dalam proses pengambilan keputusan dan pengelolaan pembangunan.

Lokasi sasaran PNPM Mandiri Perkotaan sejak tahun 2008 meliputi 8.813 kelurahan/desa di 955 kecamatan perkotaan yang tersebar di 245 kota/kabupaten di 33 provinsi diseluruh Indonesia termasuk Kota Medan. 
Lokasi pada penelitian ini adalah Kelurahan Bagan Deli yang terdiri dari 15 lingkungan dengan kondisi lingkungan yang kumuh dan memprihatinkan. Kondisi permukiman nelayan pada Kelurahan Bagan Deli yang berada tepat di sempadan sungai adalah kondisi jalan rusak dan becek karena sering terkena air pasang, lokasi yang rawan banjir air pasang, sampah yang berserakan, limbah rumah tangga yang tidak ditangani, tingkat kerusakan bangunan tinggi, jamban berada diluar rumah, mempunyai tingkat kepadatan bangunan sangat tinggi, kondisi lingkungan buruk dan kumuh, dan bangunan perumahan yang ada sebagian besar adalah semi permanen.

Pemerintah Kota Medan sudah berusaha memperbaiki kondisi diatas tersebut melalui program-program pemerintah setiap tahunnya yang bertujuan agar kondisi permukiman nelayan Kelurahan Bagan Deli menjadi lebih baik lagi.

Adapun salah satu program pemerintah yang ada pada kelurahan ini adalah Program Nasional Pemberdayaan Masyarakat (PNPM) Mandiri Perkotaan, dimana sejak tahun 2008 Kelurahan Bagan Deli merupakan lokasi sasaran dari program pemerintah tersebut. Setiap tahunnya Program Nasional Pemberdayaan Masyarakat (PNPM) Mandiri Perkotaan selalu memberikan program-program kepada masyarakat Kelurahan Bagan Deli untuk memperbaiki kondisi daerah tersebut, namun kenyataannya program-program tersebut belum cukup membantu kondisi kelurahan ini menjadi lebih baik dikarenakan rendahnya tingkat partisipasi masyarakat terhadap program pemerintah. Oleh karena itu peneliti tertarik untuk mengkaji sejauh mana tingkat partisipasi masyarakat terhadap program pembangunan yang dilakukan pemerintah terhadap Kelurahan Bagan Deli khususnya Program Nasional Pemberdayaan Masyarakat (PNPM) Mandiri Perkotaan. Penelitian ini juga dipandang perlu untuk memperolehfaktor yang menyebabkan rendahnya tingkat partisipasi masyarakat pada Kelurahan Bagan Deli agar tujuan pemerintah melalui Program Nasional Pemberdayaan Masyarakat (PNPM) Mandiri Perkotaan dapat tercapai.

\section{METODOLOGI PENELITIAN}

\section{A. Pendekatan Penelitian}

Penelitian Participatory Action Research merupakan salah satu model penelitian yang mencari sesuatu untuk menghubungkan proses penelitian ke dalam proses perubahan sosial. Perubahan sosial yang dimaksud adalah bagaimana dalam proses pemberdayaan dapat mewujudkan tiga tolak ukur, yakni adanya komitmen bersama dengan masyarakat, adanya local leader dalam masyarakat dan adanya institusi baru dalam masyarakat yang dibangun berdasarkan kebutuhan. Penelitian ini membawa proses penelitian dalam lingkaran kepentingan orang dan menemukan solusi praktis bagi masalah bersama dan isu-isu yang memerlukan aksi dan refleksi bersama, dan memberikan

kontribusi bagi teori praktis.1

PAR (Participatory Action Research) melibatkan pelaksanaan penelitian untuk mendefinisikan sebuah masalah maupun menerapkan informasi ke dalam aksi sebagai solusi atas masalah yang telah terdefinisi. PAR (Participatory Action Research) adalah "penelitian oleh, dengan, dan untuk orang" bukan "penelitian terhadap orang". PAR (Participatory Action Research) adalah partisipatif dalam arti bahwa ia 
sebuah kondisi yang diperlukan dimana orang memainkan peran kunci di dalamnya dan memiliki informasi yang relevan tentang sistem sosial (komunitas) yang tengah berada di bawah pengkajian, dan bahwa mereka berpartisipasi dalam rancangan dan implementasi rencana aksi itu didasarkan pada hasil penelitian.

Paradigma pertama, PAR (Participatory Action Research) merubah cara berfikir kita tentang penelitian dengan menjadikan penelitian sebuah proses partisipasi. PAR (Participatory Action Research) itu sendiri adalah sebuah kondisi yang diperlukan dimana orang memainkan peranan kunci di dalamnya dan memiliki informasi yang relevan tentang sistem sosial atau komunitas, yang tengah berada di bawah studi. "Subyek ${ }^{\text {ee }}$ penelitian lebih baik untuk dirujuk atau menjadi rujukan sebagai anggotaanggota komunitas, dan mereka berpartisipasi dalam rancangan, implementasi, dan eksekusi penelitian.2

PAR (Participatory Action Research) juga adalah sebuah pergeseran dalam pengertian bahwa ke dalamnya termasuk elemen aksi. PAR (Participatory Action Research) melibatkan pelaksanaan penelitian untuk mendefinisikan sebuah masalah maupun penerapan informasi dengan mengambil aksi untuk menuju solusi atas masalah-masalah yang terdefinisikan. Anggota-anggota komunitas berpartisipasi dalam rancangan dan implementasi dalam rencana tindak strategis didasarkan pada hasil penelitian.

Paradigma kedua, PAR (Participatory Action Research) adalah proses dimana komunitas-komunitas berusaha mempelajari masalah secara ilmiah dalam rangka memandu, memperbaiki, dan mengevaluasi keputusan dan aksi mereka. Cara-cara penelitian yang selama ini biasa dilakukan kalangan akademisi dan peneliti dalam komunitas kita, justru dapat menjadi tantangan dan ancaman bagi sebuah komunitas. Hubungan antara penelitian ilmiah (intellectual research) dapat menjadi intrusive dan exclusive. Kedua tipe penelitian ini juga dapat melenyapkan bagian-bagian penting dan vital dari sebuah poyek penelitian yakni pengalaman hidup nyata, mimpi, pikiran, kebutuhan, kemauan dari anggota komunitas.

PAR (Participatory Action Research) menawarkan metode-metode untuk merubah hakekat hubungan antara orang, dengan organisasi yang biasanya dikejar poyek penelitian dan pengembangan. Hubungan ini termasuk bagaimana kita memahami peran kita sebagai fasilitator, bukan sebagai experts, bagaimana kita mengelola hubungan dengan lembaga pendidikan dan lembaga bisnis, dan bagaimana kita bekerja satu sama lain sebagai siswa, guru, tetangga, dan anggota komunitas.

\section{B. Prosedur Penelitian}

Seperti yang sudah diuraikan di muka. Maka prinsip pendidikan dan pelatihan partisipatif (kritis) dapat dirumuskan sebagai berikut:

Pertama, Belajar dari realitas atau pengalaman. Prinsip pertama ini menekankan bahwa yang dipelajari dalam pendidikan ini bukan hanya teori yang tidak ada kaitan dengan kenyataan dan kebutuhan. Jadi bahan pelajaran dalam pendidikan ini berangkat (bersumber) dari kenyataan dan kebutuhan. Konsep- konsep atau teori-teori yang ada, digunakan untuk membantu dalam menganalisa kenyataan dan kebutuhan. Dengan begitu, tidak ada pengetahuan seseorang lebih tinggi dari yang lainnya. Karena dalam kenyataannya, setiap orang memiliki pengalaman berbeda. Pengalaman tersebut harus diakui sebagai sebuah modal dalam mengembangkan pengetahuan baru. 
Kedua, Tidak menggurui. Berdasarkan kepada prinsip yang pertama, maka di dalam pendidikan partisipatif tak ada "guru" dan tak ada "murid yang digurui". Semua orang yang terlibat dalam proses pendidikan ini adalah "guru sekaligus murid" pada saat yang bersamaan. Keduanya sama-sama mencurahkan perhatian pada obyek yang sedang dikaji. Kedudukan orang luar, harus didudukkan sebagai seorang fasilitator.

Ketiga, Proses belajar dijalankan dengan Dialogis. Karena tidak ada lagi guru atau murid, maka proses yang berlangsung bukan lagi proses "mengajar-belajar" yang bersifat satu-arah, tetapi proses belajar yang dialogis. Proses belajar yang dialogis adalah proses belajar yang menjamin terjadinya "komunikasi aktif dan kritis"dalam berbagai bentuk kegiatan, seperti diskusi kelompok, diskusi pleno, bermain peran, dan sebagainya. Proses belajar dialogis ini juga didukung media belajar yang memadai, seperti alat peraga, grafika, audio-visual, dan sebagainya. Proses belajar ini dimaksudkan untuk mendorong semua orang terlibat dalam proses belajar.

Adapun langkah-langkah yang akan dilakukan dalam proses belajar ini adalah sebagai berikut:

1. Mengalami/Melakukan

Proses "mengalami" adalah memberikan kesempatan kepada peserta belajar untuk memiliki atau merasakan suatu pengalaman. Memberikan pengalaman langsung dalam bentuknya adalah peserta belajar dilibatkan dan bertindak untuk merasakan dan mengalami langsung. INGAT!!! Pengalaman adalah guru yang paling baik.

2. Mengungkapkan

Dari pengalaman tersebut, peserta belajar mengungkapkan ,apa ${ }^{\text {ee }}$ yang sudah dialami, atau kesan dari perasaannya, termasuk pengalaman dari Warga belajar lain. Pengalaman ini selanjutnya menjadi bahan (data) untuk diolah selanjutnya.

3. Mengolah dan menganalisis

Setelah melakukan langkah pengungkapan, peserta belajar secara bersama- sama mengkaji semua bahan (data) yang telah diungkapkan (berdasarkan pada pengalaman) tersebut. Hasil analisis ini, kemudian dihubungkan dengan pengalaman baru untuk dibahas dan dianalisis.

4. Menyimpulkan dan Menerapkan

Ahirnya peserta sendiri yang diharapkan memetik kesimpulan dari analisa yang mereka telah lakukan. Tujuan utama dari langkah menyimpulkan ini adalah menuju pada aksi pelaksanaan, penerapan, atau implementasi dari apa yang warga belajar telah diskusikan.

\section{Subyek Penelitian}

Dalam teori PAR terdapat siklus yang dijadikan tolak ukur keberhasilan proses penelitian berbasis pemberdayaan masyarakat. Adapun siklus tersebut dikenal dengan istilah KUPAR (to Know, to Understand, to Plan, to Action dan to Reflection). To Know (untuk mengetahui) merupakan proses awal dalam pemberdayaan dengan mempertimbangkan pandangan subyektif peneliti terhadap kehidupan masyarakat yang diteliti, seperti mengidentifikasi SDA dan SDM, serta membangun kesepakatan sehingga peneliti diterima oleh masyarakat tersebut.

To Understand (untuk memahami) dimaknai sebagai suatu proses dimana peneliti dan masyarakat yang diberdayakan mampu mengidentifikasi permasalahanpermasalahan yang ada dalam kehidupan mereka, kemudian dikolerasikan dengan aset- 
aset yang dimiliki masyarakat, sehingga dapat mewujudkan komitmen masyarakat dalam menyelesaikan isu-isu strategis yang ada dalam kehidupan mereka.

To Plan (untuk merencanakan) dimaknai sebagai proses merencanakan aksi- aksi strategis dalam menyelesaikan persoalan yang muncul dalam masyarakat. Perencanaan ini mempertimbangkan keseimbangan anatara human resources dan natural resources serta alur stakeholder yang menghimpun masyarakat tersebut. Tahap perencanaan ini harus dimaksimalakan dengan kesertaan penuh masyarakat atas penyelesaian masalahnya sendiri. Sehingga pemberdayaan tidak hanya diartikan sebagai perubahan sosial saja, namun juga media pendidikan masyarakat.

To Action (melancarkan aksi) merupakan implementasi produk pemikiran masyarakat untuk membangun, mengelola, merubah, menajamkan aset-aset yang dimiliki masyarakat sehingga dapat difungsikan secara optimal dan proposional.

To Reflection (refleksi) merupakan tahapan dimana peneliti dan masyarakat mengevaluasi dan memonitoring aksi pemberdayaan yang telah dilakukan sehingga pemberdayaan menjadi terarah dan terukur.

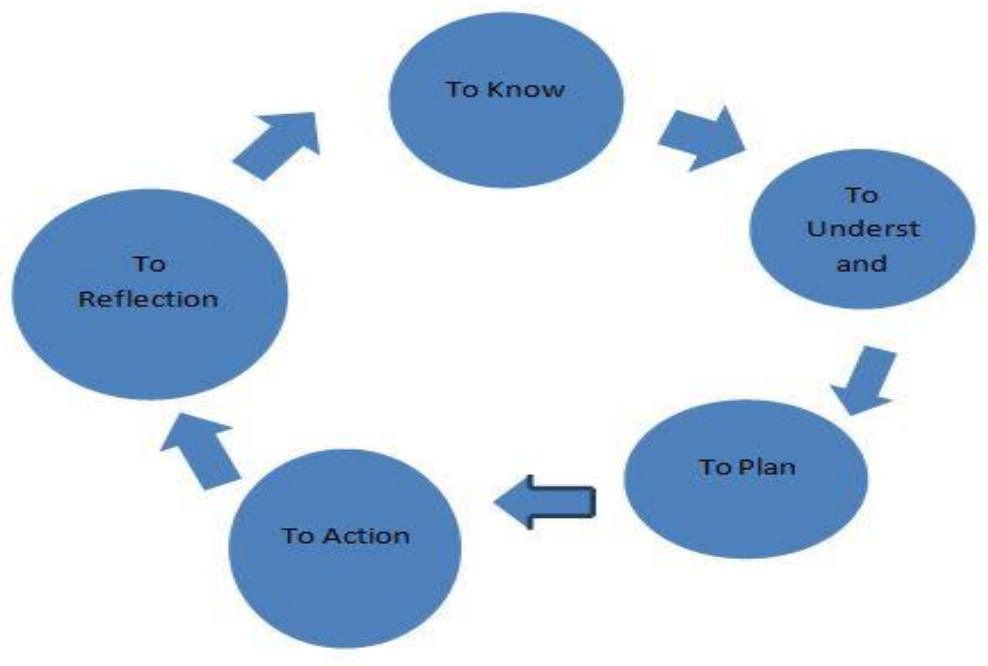

Gambar 1.. Siklus Participatory Action Research

\section{Teknis Pelaksanaan Penelitian}

Pemetaan awal dilakukan peneliti dengan mempertimbangkan kondisi umum masyarakat miskin Wonokusumo. Dari riset bersama melalui pengamatan peneliti secara obyektif dan dikuatkan oleh seorang kader organisasi pemberdayaan perempuan di wilayah tersebut diketahui bahwa permasalahan yang dihadapi oleh masyarakat disini memiliki latar belakang, lingkungan sosial dan karakteristik yang berbeda-beda.

Sebagai contoh, sebut Ibu Suryati, beliau merelakan diri untuk menjadi pegawai toko karena kondisi keluarganya yang tidak mumpuni dari segi ekonomi. Selain itu, ketidakmampuannya untuk bersaing dalam dunia kerja karena keterbatasan sumber daya manusia mengakibatkan beliau bekerja keras untuk memenuhi kebutuhan seharihari sebab suaminya tidak bekerja. Rumah yang dihuni beliau juga adalah rumah kontrakan yang berukuran sangat kecil 3x3 meter yang letaknya berdekatan dengan kamar mandi dan WC umum yang digunakan oleh seluruh warga kontrakan. Kondisi 
rumahnya jauh dari kata sehat. Dindingnya yang hanya terbuat dari triplek, ventilasinya tidak memadai bahkan bisa dikatan pintunya menjadi ventilasi utama.

\section{E. Evaluasi}

Orientasi proses evaluasi dalam riset aksi partisipatif menekankan pada penjabaran proses dari aksi pemberdayaan tersebut. Maka dalam proses evaluasi yang dilakukan untuk menanggapi aksi-aksi yang telah dilaksanakan adalah mempertimbangkan kekurangan, kelebihan, kelemahan dan kekuatan dari aksi pemberdayaan yang telah dilakukan.

Dalam tahan evaluasi, peneliti bersama keluarga miskin berpandangan tentang bagaimana upaya pemberdayaan yang telah dilakukan tidak tiba-tiba berhenti di tengah jalan dengan alasan-alasan tertentu, baik karena pihak lain maupun masalah-masalah dari pihak intern sendiri, maka dibutuhkan adanya local leader dan komitmen bersama guna memonitoring dan meluaskan skala jaringan dalam pelaksanaan program pemberdayaan jangka pajang.

\section{METODOLOGI PENELITIAN AKSI PARTISIPATIF}

\section{A. Langkah-langkah Riset Aksi Dalam Metodologi PAR}

Pemetaan awal merupakan pemetaan yang dilakukan oleh peneliti untuk mengetahui situasi dan keadaan sosial yang ada di masyarakat. Pemetaan ini dilakukan bersama dengan masyarakat. Dengan pemetaan ini peneliti dapat mengetahui letak geografis Dusun Sempol dan batas-batas Dusun Sempol. Selain itu jumlah penduduk, kebudayaan, keagamaan, pendidikan dan perekonomian masyarakat dapat di dapat dari kegiatan pemetaan awal.

1. Membangun Hubungan Kemanusiaan

Dalam melakukan penelitian pendampingan ini peneliti juga perlu membangun hubungan kemanusiaan dengan masyarakat. Hal ini diperlukan untuk membangun kepercayaan masyarakat terhadap peneliti. Dalam membangun hubungan kemanusiaan ini peneliti berbaur dengan masyarakat dengan mengikuti kegiatan-kegiatan yang ada dalam masyarakat, yaitu tahlilan, sholat berjama'ah dll.

Langkah-langkah ini dilakukan supaya peneliti bisa menyatu menjadi simbiosis mutualisme untuk melakukan riset, belajar memahami masalahnya, dan memecahkan persoalannya bersama-sama (partisipatif).

2. Penentuan Agenda Riset Untuk Perubahan Sosial

Penentuan agenda riset dalam penulisan ini di perlukan oleh peneliti. Bersama komunita, peneliti mengagendakan program riset melalui teknik Partisipatory Rural Aprasial (PRA) untuk memahami persoalan masyarakat yang selanjutnya menjadi alat perubahan social. Sambil merintis membangun kelompok-kelompok komunitas, sesuai dengan potensi dan keragaman yang ada.

3. Pemetaan Partisipatif (Participatory Mapping)

Bersama Komunitas melakukan pemetaan wilayah, maupun persoalan yang dialami masyarakat. Pemetaan lebih difokuskan pada jumlah ternak yang dimiliki oleh masyarakat Dusun Sempol.

4. Merumuskan Masalah Kemanusiaan

Komunitas merumuskan masalah mendasar hajat hidup kemanusiaan yang dialaminya. Seperti persoalan pangan, papan, kesehatan, pendidikan, energy, lingkungan hidup, dan persoalan utama kemanusiaan lainya. Adapun persoalan 
yang ada di tengah- tengah komunitas peternak Dusun Sempol ini adalah kurangnya kesadaran masyarakatbakan pola hidup sehat.

5. Menyusun Strategi Gerakan

Komunitas menyusun strategi gerakan untuk memecahkan problem kemanusiaan yang telah dirumuskan. Menentukan langkah sistematik, menentukan pihak yang terlibat (stakeholders), dan merumuskan kemungkinan keberhasilan dan kegagalan program yang direncanakanya serta mencari jalan keluar apabila terdapat kendala yang menghalangi keberhasilan program.

6. Pengorganisasian Masyarakat

Komunitas didampingi peneliti membangun pranata-pranata sosial. Baik dalam bentuk kelompok-kelompok kerja, maupun lembaga-lembaga masyarakat yang secara nyata bergerak memecahkan problem sosialnya secara simultan. Demikian pula membentuk jaringan-jaringan antar kelompok kerja dengan lembaga-lembaga lain yang terkait dengan program aksi yang direncanakan.

7. Aksi Perubahan

Aksi memecahkan problem dilakuakan secara simultan dan partisipatif. Program pemecahan persoalan kemanusiaan bukan sekedar untuk menyelesaikan persoalan itu sendiri, tetapi merupakan proses pembelajaran masyarakat, sehingga terbangun pranata baru dalam komunitas dan sekaligus memunculkan community organizer (pengorganisir dari masyarakat sendiri) dan akhirnya akan muncul local leader (pemimpin lokal) yang menjadi pelaku dan pemimpin perubahan.

8. Refleksi (Teoritisasi Perubahan Sosial)

Peneliti bersama komunitas merumuskan teoritisasi perubahan social berdasarkan atas hasil riset, proses pembelajaran masyarakat, dan program-program aksi yang telah terlaksana, peneliti dan komunitas merefleksikan semua proses dan hasil yang diperolehnya (dari awal sampai akhir). Refleksi teoritis dirumuskan secara bersama, sehingga menjadi sebuah teori akademik yang dapat dipresentasikan pada khalayak publik sebagai pertanggung jawaban akademik.

9. Meluaskan Skala Gerakan dan Dukungan

Keberhasilan program PAR tidak hanya diukur dari hasil kegiatan selama proses, teatapi juga diukur dari tingkat keberlanjutan program (sustainability) yang sudah berjalan dan munculnya pengorganisir-pengorganisir serta pemimpin local yang melanjutkan program untuk melakukan aksi perubahan. Oleh sebab itu, bersama komunitas peneliti memperluas skala gerakan dan kegiatan. Mereka membangun kelompok komunitas baru di wilayah-wilayah baru yang dimotori oleh kelompok dan pengorganisir yang sudah ada. Bahkan diharapkan komunitas-komunitas baru itu dibangun oleh masyarakat secara mandiri tanpa harus difasilitasi oleh peneliti. Dengan demikian masyarakat akan bisa belajar sendiri, melakukan riset dan memecahkan problem sosialnya secara mandiri.

\section{B. Tehnik Pendampingan dan Penelitian}

Dalam penggalian data penulisan skripsi ini menggunakan metode pendampingan yang berbasis Participatory Action Research (PAR) yaitu metode riset yang dilaksanakan secara partisipatif di antara warga masyarakat dalam suatu komunitas aras bawah yang semangatnya untuk mendorong terjadinya aksi-aksi transformatif melakukan pembebasan masyarakat dari belenggu ideologi dan relasi 
kekuasan (perubahan kondisi hidup yang lebih baik.

Adapun langkah-langkah dalam PAR, yaitu:

1. Penyiapan Sosial (Merancang Komunikasi Kemanusiaan)

Dalam penyiapan sosial ini berarti mengetahui dan memahami masyarakat. Dalam proses ini pendamping berbaur dengan masyarakat untuk mengenali dan memahami masyarakat. Dengan melalui inkulturasi yang di bangun maka akan menciptakan komunikasi dengan masyarakat. Karena Peneliti berfikir bahwa jika komunikasi yang di bangun dengan masyarakat kuat maka aka lebih mudah untuk membangun partisipasi masyarakat dalam membantu peneliti.

Penyiapan social di lakuakan dengan cara memahami kelompok yang tidak terorganisir dalam masyarakat, memahami peran dan fungsi lembaga yang ada di masyarakat dan mengenali tradisi yang dilakukan masyarakat.

2. Community Riset Social Problem Diagnosti

Yaitu menganalisis masalah yang ada di masyarakat. Dengan mengetahui dan memahami keseharian masyarakat maka pendamping dapat mengidentifikasi masalah. Selain itu pendamping juga melakukan FGD bersama masyarakat untuk mengetahui dan memahami permasalahan yang ada. Pohon masalah pun juga di buat bersama masyarakat.

Selain itu yang di lakukan pendamping dalam menganalisis masalah yaitu dengan maping, transek, memahami alur sejarah dan tradisi masyarakat. Diagram alur, diagram ven dan analisis social juga di gunakan dalam memahami permasalahan yang terjadi di masyarakat.

\section{Planning}

Istilah pengorganisasian rakyat (people organizing) atau yang lebih juga dikenal dengan istilah pengorganisir masyarakat (community organizing) sebenarnya adalah suatu peristilahan yang sudah menjelaskan dirinya sendiri. Istilah ini memang mengandung pengertian yang luas dari dua akar katanya. Istilah rakyat disini tidak hanya berarti satu perkauman (community)yang khas, dalam konteks yang lebih luas juga pada masyarakat (society)pada umumnya. Istilah pengorganisasian disini lebih diartikan sebagai suatu kerangka proses menyeluruh untuk memecahkan masalah di tengah masyarakat. Sehingga bisa juga diartikan suatu cara pendekatan dalam melaksanakan kegiatan dalam rangka memecahkan masalah tersebut.

Planning adalah pemecahan masalah. Pemecahan masalah ini di lakukan bersama masyarakat. Dari pohon masalah yang di buat bersama masyarakat maka muncul pohon harapan yang berisikan harapan-harapan masyarakat dalam memecahkan masalah tersebut. Pendamping bersama masyarakat merencanakan program yang akan di laksanakan. Dengan membuat proposal dan bekerja sama dengan pihak-pihak terkait. Pendamping bersama masyarakat mengadakan pertemuan-pertemuan dalam perencanaan kegiatan yang akan di laksanakan.

\section{Political Action}

Yaitu membentuk kelompok-kelompok social baru. Hal ini dilakukan untuk pemecahan masalah. Dengan membangun leadership atau seorang pemimpin yang dapat mengorganisir masyarakat dan dapat melakukan analisis terarah sehingga mendorong proses transparansi atas semua pihak dan semua permasalahan. Kegiatan ini dilakukan bersama partisipasi masyarakat. Aksi yang di lakukan ini menjawab harapan-harapan masyarakat. 
Dalam membangun membangun partisipasi masyarakat sebelum melakukan aksi tidak bermaksud untuk menumbuhkan partisipasi atas nama, partisipasi pasif, partisipasi lewat konsultasi maupun partisipasi fungsional. Melainkan partisipasi yang dibangun adalah partisipasi interaktif, dimana ide dalam berbagai kegiatan mulai perencanaan dan evaluasi melibatkan peran aktif masyarakat. Sehingga diharapkan masyarakat dapat mengambil inisiatif sendiri, melaksanakan kegiatan secara mandiri dan memobilisasi sumber daya yang dibutuhkan dari masyarakat sendiri.

5. Reflection

Yaitu tindakan dari hasil kegiatan atau menilai keberhasilan dan kekurangan semua kompenen aktifitas terhadap perubahan sosial yang menjadi visi masyarakat.

Pendamping merefleksi dan menganalisis dari hasil kegiatan yang telah di lakukan.

\section{DAFTAR PUSTAKA}

https://media.neliti.com/media/publications/57353-ID-action-research-desainpenelitian-integr.pdf (diungaah 9 Juli 2018)

Adi, Isbandi R. (2013). Intervensi Komunitas dan Pengembangan Masyarakat: Sebagai Upaya Pemberdayaan Masyarakat. Jakarta : Rajawali Pres

Coghlan, David \& Brannick, Teresa. (2005). Doing Action Research in Your Own Organization, 2nd edition. London: Sage Publication Ltd.

Koshy, Valsa. (2005). Action Research for Improving Practice: A Practical Guide. London: Sage Publication Ltd.

McNiff, Jean \&Whitehead,Jack. (2002). Action Research: Principles and Practice. London: RoutledgeFalmer.

Stringer, Ernest T. (1996). Action Research: A Handbook for Practitioners. Los Angeles: Sage Publication, Inc.

Suharto, Edi. (1997). Pembangunan, Kebijakan Sosial dan Pekerjaan Sosial: Spektrum Pemikiran. Bandung: Lembaga Studi Pembangunan STKS.

Yaumi, M. \& Damopolil, M. (2014). Action Research: Teori, Model, \& Aplikasi. Jakarta: Penerbit Kencana. 